\title{
Morphometric and Reproductive Traits of Tropical Caridean Shrimps
}

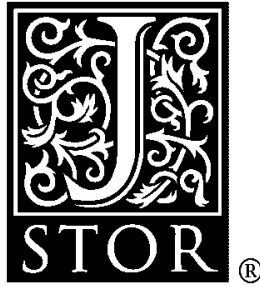

\author{
Klaus Anger; Gloria S. Moreira
}

Journal of Crustacean Biology, Vol. 18, No. 4. (Nov., 1998), pp. 823-838.

Stable URL:

http://links.jstor.org/sici?sici=0278-0372\%28199811\%2918\%3A4\%3C823\%3AMARTOT\%3E2.0.CO\%3B2-\%23

Journal of Crustacean Biology is currently published by The Crustacean Society.

Your use of the JSTOR archive indicates your acceptance of JSTOR's Terms and Conditions of Use, available at

http://www.jstor.org/about/terms.html. JSTOR's Terms and Conditions of Use provides, in part, that unless you have obtained prior permission, you may not download an entire issue of a journal or multiple copies of articles, and you may use content in the JSTOR archive only for your personal, non-commercial use.

Please contact the publisher regarding any further use of this work. Publisher contact information may be obtained at http://www.jstor.org/journals/crustsoc.html.

Each copy of any part of a JSTOR transmission must contain the same copyright notice that appears on the screen or printed page of such transmission.

The JSTOR Archive is a trusted digital repository providing for long-term preservation and access to leading academic journals and scholarly literature from around the world. The Archive is supported by libraries, scholarly societies, publishers, and foundations. It is an initiative of JSTOR, a not-for-profit organization with a mission to help the scholarly community take advantage of advances in technology. For more information regarding JSTOR, please contact support@jstor.org. 


\title{
MORPHOMETRIC AND REPRODUCTIVE TRAITS OF TROPICAL CARIDEAN SHRIMPS
}

\author{
Klaus Anger and Gloria S. Moreira
}

\begin{abstract}
A B S T R A C T
Life-history traits were studied in one marine and four fresh-water shrimps from tropical regions of western South America: Palaemon northropi, P. pandaliformis, Macrobrachium acanthurus, and $M$. olfersii (Palaemonidae). Occasional data are given for Macrobrachium carcinus and an atyid shrimp, Potimirim potimirim. Size was measured as total body length (TBL), carapace length (CL), and telson length (TL), weight as dry weight (W), and realized fecundity as number of eggs per female. Size and W of eggs were determined in an early stage of development. Relationships between measurements of size, weight, and fecundity are described with regression equations. Significant species- and sex-specific variation was found in the slopes of the allometric TBL-W relationship. In the 2 species of Palaemon, females grew to a larger size than males; they showed also a steeper W increase with increasing TBL. Opposite patterns were observed in $M$. acanthurus and $M$. olfersii, suggesting different traits on the generic level. The minimum sexable size (minimum size of males with appendix masculina) was unrelated to the species-specific maximum size. Size at the onset of female maturity (minimum size with eggs) was larger in $M$. acanthurus than in the other species ( 29 versus $20-22 \mathrm{~mm}$ ); W at the onset of female maturity increased with the maximum size of a species. Regressions of egg number on TBL indicated the highest overall level as well as the strongest size-dependence of fecundity in $M$. olfersii; these parameters were lowest in $P$. pandaliformis. The reproductive output (RO:W of egg mass in relation to female body W) was lowest in the only marine species studied here, $P$. northropi (14.4 versus $18.6-21.7 \%)$. With the possible exception of the RO, the life-history traits of these tropical shrimps appear unrelated to the climatic origin or habitat of a species.
\end{abstract}

Growth and reproduction are important aspects of the ecology and life history of a species. In crustaceans, they have been quantified with several measurements of body size, weight, and fecundity, and relationships between these characteristic data have been described with linear or nonlinear regression models. While growth may be quantified as an increase in total body length (TBL), carapace length (CL), telson length (TL), fresh weight $(\mathrm{FW})$, or dry weight $(\mathrm{W})$, reproduction is frequently measured in terms of fecundity. We distinguish the concepts of potential fecundity (i.e., the number of oocytes in the ovary), realized fecundity (number of eggs attached under the abdomen), and actual fecundity (number of larvae hatched; Corey, 1991). Depending on the purpose of a particular study and the kind of materials available, some of these measures of growth and reproduction are more convenient than others. In cultivation experiments with a limited number of living individuals available, for instance, nondestructive sampling techniques, such as size measurements in cast exuviae, may be required. Since TBL is, in this case, often difficult or impossible to measure, $\mathrm{CL}$ or TL may yield more reliable growth data. Furthermore, W measurements are not possible without sacrificing valuable live material. Hence, it is important to know quantitative relationships between measurements of size, weight, and reproduction, which can then be used to predict one from another.

The parameters of regression equations are useful not only for conversions, but also as indices for intra- and interspecific comparisons of morphometric or reproductive traits. As further key life-history parameters, the absolute or relative "size at the onset of maturity" (SOM, Wenner, 1985; RSOM, Charnov, 1990) have been used to compare the reproductive performance of different species or populations. The RSOM compares the minimum size of sexually mature individuals with the theoretical maximum, represented by the asymptotic parameter $\mathrm{L}_{\infty}$ of the von Bertalanffy growth equation. As another comparative index of the investment by a species in offspring production, the "reproductive output" (RO) is frequently given in the literature (Hines, 1982, 1988, 1991; Clarke et al., 1991; Lardies and Wehrtmann, 1996). This is usually measured as a weight ratio between 
the egg mass (i.e., realized fecundity) and female body weight (on an FW or W basis). In caridean shrimps, quantitative relationships among measures of growth and reproduction have been described for several taxa (e.g., Clarke et al., 1991; Corey and Reid, 1991; Reid and Corey, 1991; Lardies and Wehrtmann, 1996). Most of the existing data, however, originate from boreal and subtropical rather than tropical species.

In the present investigation, we measured body size (as TBL, CL, and TL), dry weight (W), female reproduction (realized fecundity; as number of eggs), and the size and $\mathrm{W}$ of eggs in four species of tropical palaemonid shrimps from the coastal region of the state of São Paulo, Brazil: Palaemon (Palaeander) northropi Rankin, 1898; P. (Palaemon) pandaliformis Stimpson, 1871; Macrobrachium acanthurus Wiegmann, 1836; and $M$. olfersii Wiegmann, 1836. For all of these species, morphometric relationships between different measurements of size as well as those between size, weight, and fecundity are described with regression equations. From these data, we estimate female SOM, RSOM, and $\mathrm{RO}$, and the minimum size of males with a developed appendix masculina (i.e., with an identifiable sex) is given. In addition, a few occasional data on size and fecundity are presented for two further species, Macrobrachium carcinus Linnaeus, 1758 , and $\mathrm{Po}$ timirim potimirim Müller, 1881 (Atyidae).

Thus, our data allow for intra- and interspecific comparisons of life-history traits in four shrimp taxa belonging to the same family, the Palaemonidae (including two subgenera of the genus Palaemon), and preliminary comparisons with another palaemonid and an atyid shrimp. All these species are widely distributed in tropical regions of eastern South America, some also in Central America, the Caribbean, and the southeastern United States. They are characterized by different specific body size (small Palaemon versus large Macrobrachium) and different life styles (fresh-water versus marine).

Species Studied: Brief Summary of Life History and Distribution.-Palaemon northropi is a marine shrimp that is commonly found in intertidal rock pools (Moreira and McNamara, 1984) and on sandy mud flats near mangrove areas (Chace, 1972). All four other species studied (P. pandaliformis, Mac- robrachium acanthurus, $M$. olfersii, $M$. carcinus, Potimirim potimirim) live as adults in fresh water (Holthuis, 1952, 1959; Chace and Hobbs, 1969). However, experimental evidence suggests that their life history follows an "export strategy," i.e., their larvae leave the adult habitat with outflowing currents and develop subsequently in adjacent brackish estuaries or coastal marine waters. As a consequence of their limited adaptation to the limnic parental environment, the larvae can survive in fresh water for a maximum of about one week, but they are not able to develop there beyond the first zoeal stage. Brackish and sea-water conditions, in contrast, allow for successful development from hatching to metamorphosis (Choudhury, 1971a, b; Dobkin, 1971; Dugger and Dobkin, 1975; Moreira et al., 1979; McNamara et al., 1980; Moreira and McNamara, 1984; Bakker, 1989). The larvae of the fully marine species $P$. northropi, in contrast, are stenohaline, surviving for only a few hours in fresh water (Moreira et al., 1982; Moreira and McNamara, 1984).

All species studied occur in coastal waters or adjacent fluvial systems, respectively, in the tropical zones of eastern South America, with Brazil as their southern limit of distribution. The geographic ranges of $P$. northropi, $M$. olfersii, $M$. carcinus, and $P$. potimirim extend north to Florida (not including the Caribbean islands for $M$. olfersii and $P$. potimirim), for $P$. pandaliformis to Guatemala, and for $M$. acanthurus to North Carolina and Bermuda (Holthuis, 1952, 1959; Smalley, 1963; Chace and Hobbs, 1969; Holthuis and Provenzano, 1970; Chace, 1972; Dugger and Dobkin, 1975; Gore et al., 1978; López and Pereira, 1994). Some fresh-water shrimps, in particular species of Macrobrachium, have been extensively studied with respect to larval metabolism and salinity tolerance, osmoregulation, and the function of neuroendocrine regulation systems (e.g., Souza and Moreira, 1987; McNamara et al., 1990; Santos and McNamara, 1996). In contrast, surprisingly little is known about the basic morphometric and reproductive traits of these species.

\section{MATERIALS AND METHODS}

This investigation was carried out in April 1995 and February 1996 at the marine biological center (CEBIMar) of the University of São Paulo (USP), near the town of São 
Sebastião, Brazil. Fresh-water shrimps (Palaemon pandaliformis, Macrobrachium acanthurus, $M$. olfersii, $M$. carcinus, and $P$. potimirim) were caúght with hand nets (approximately 3-mm mesh size) from the lower reaches of creeks that are located near the CEBIMar (Pitangueira; Guaecá) and on the island of Ilhabela (approximately $23^{\circ} 49^{\prime} \mathrm{S}, 45^{\circ} 27^{\prime} \mathrm{W}$ ). The salinity at these sampling sites was usually close to $0 \%$, but, sometimes, when sea water intruded into the mouths of the creeks with high tide or landward winds, up to $6 \%$ o were measured (by means of a hand refractometer). The temperature varied with weather conditions, tide, and time of day between $22^{\circ}$ and $30^{\circ} \mathrm{C}$. Marine shrimps ( $P$. northropi) were caught in intertidal rock pools on the beach in front of the CEBIMar. The salinity in this habitat was approximately $35 \%$, and the temperature about $25^{\circ} \mathrm{C}$.

Shrimps were transported live to the laboratory and maintained for up to 2 days in aquaria with either tap water or sea water. Immediately before measurements, they were taken out of the water and killed by exposure to $-10^{\circ} \mathrm{C}$ for a few minutes. Total body (TBL), carapace length (CL), and telson length (TL) were measured under a dissecting microscope (Wild M3B) with a calibrated eye-piece micrometer to the nearest $0.01 \mathrm{~mm}$; in large individuals, TBL was measured with vernier calipers to the nearest $0.1 \mathrm{~mm}$. In our material, $\mathrm{CL}$ is defined as the shortest distance from the rear margin of the eye orbit to the median posterior edge of the carapace. TBL was measured from the rear margin of the eye orbit to the base of the median distal telson spine, and TL was taken from the midanterior margin of the telson to the base of the median distal telson spine.

To determine the presence of an appendix masculina, the second pleopod was dissected free and inspected under a dissecting microscope (in small individuals under a compound microscope, Nikon Labophot 2). This allowed for an identification of the minimum body size at which individuals of a given species may be sexed (in the following termed "minimum sexable size," MSS). Since smaller (not sexable) individuals were morphologically similar to young females, we counted these as females. Theoretically, juvenile males below the MSS that were erroneously "sexed" as females may have introduced a statistical error into our morphometric data of female shrimps. However, we assume that this bias did not significantly change the morphometric or other regressions given in this paper, because (1) juveniles smaller than the MSS show probably no significant sexual dimorphism, and (2) this size group constituted in general only a minor fraction of our material (5 individuals in both $P$. northropi and $P$. pandaliformis, 14 in $M$. olfersii, and none in the other species). This problem must be considered in population studies, when the sex ratio is given; in that case, a "juvenile" category must be distinguished from safely identified males and females.

In ovigerous females, the eggs were carefully removed from the pleopods and counted under a dissecting microscope. Large egg masses $(>1,000$ eggs; for example, in large females of Macrobrachium) were transferred to preweighed and numbered pieces of aluminum foil, dried at $105^{\circ} \mathrm{C}$ to constant weight (for at least $15 \mathrm{~h}$ ), and total dry weight $(\mathrm{W})$ of the egg mass determined to the nearest $0.1 \mathrm{mg}$ on a Mettler laboratory balance. The egg number was in these cases estimated from the average $\mathrm{W}$ of one egg (determined in subsamples; see below).

A small sample of eggs was inspected under a compound microscope in order to identify the stage of embryonic development and to measure egg size (longest and shortest diameter, to the nearest $5 \mu \mathrm{m} ; N=10$ eggs per female). Embryonic development was classified in three categories: (I) more than two-thirds of the egg volume occupied by yolk, no eye pigments visible, embryo showing little or no differentiation, (II) phase of eye formation and embryonic differentiation (segmentation, development of appendices), heart beat visible but often irregular, yolk occupying more than one-third of egg volume, and (III) eye fully developed, heart beat regular, differentiation of appendages in final phase, yolk occupying less than one-third of egg volume.

During a short preliminary study in 1995, body size and fecundity were measured in a total of 23 ovigerous $P$. pandaliformis. Egg size was determined in different stages of embryonic development in 17 individuals of $P$. pandaliformis, $15 \mathrm{M}$. acanthurus, $10 \mathrm{M}$. olfersii, and 1 $P$. potimirim. In the 1996 study, the total body W of shrimps and the average $\mathrm{W}$ and elemental composition of eggs were also measured. After the measurements of body size (TBL, CL, TL), determination of sex, and removal of eggs (where applicable), the shrimps were transferred to aluminum foil, and $\mathrm{W}$ was measured as described above for egg masses. Samples of eggs $(N=5$ replicates, with 10 eggs each) in different stages of embryonic development were transferred to preweighed tin cartridges and frozen at $-20^{\circ} \mathrm{C}$ for later determinations of $\mathrm{W}$ and elemental composition (Anger and Harms, 1990).

In total, the material of the present paper comprises morphometric and weight measurements from $N=93$ individuals of $P$. northropi, $123 P$. pandaliformis (W data for only $N=100), 155 M$. acanthurus, and $119 \mathrm{M}$. olfer sii; fecundity data were available from $N=25,74,29$, and 49 ovigerous females, respectively. Additional data of size, weight, and fecundity were obtained from 12 females of $P$. potimirim (8 of these were ovigerous) and 3 of $M$. carcinus.

Statistical analyses followed standard methods as described by Sokal and Rohlf (1995). The data were first tested for normality and homoscedasticity (goodness-offit $G$ test; Durbin-Watson Statistic; no significant deviations found) before parametric tests were applied. Quantitative relationships between different measurements of body size (TBL, CL, TL), dry weight (W), and fecundity (egg number) were described by means of leastsquare regressions (with or without logarithmic transformation of data). Correlation and regression coefficients were tested for significant deviations from zero (ANOVA). Slopes of different regression equations were compared with each other employing multiple ANCOVA, intercepts with the $Y$-axis with an ANOVA (i.e., after removal of the interaction term). Percentage figures (reproductive output, RO) were arcsin-transformed before pairwise interspecific comparisons were made (Student's $t$-test) or tested with ANCOVA for size dependence. The following levels of statistical significance are distinguished in the paper: $P<0.05, P<0.01, P<0.001$.

Since the morphometric relationships between TBL, $C L$, and TL are usually described with a linear regression model (Lovett and Felder, 1989; Dall et al., 1990; Gabche and Hockey, 1995), but sometimes as a power function (i.e., as a linear function after logarithmic transformation of both the dependent and the independent variables; Wickins, 1972; Rodríguez, 1987), we give both types of regression to allow for intra- and interspecific comparisons with all literature data. In relationships between fecundity and size or W, we applied exclusively the generally accepted allometric model (see, e.g., Hartnoll, 1985). 
Table 1. Range of total body length (TBL, mm) and dry weight (W, mg) of males and females (M, F); size at onset of maturity (SOM, minimum TBL and W of ovigerous females); average size and W of eggs in an early stage of development (largest $\times$ smallest diameter, $\mathrm{mm} ; \mathrm{W}, \mu \mathrm{g}$ ); range of fecundity (ègg number) and reproductive output (RO, total egg mass in $\%$ of female $\mathrm{W}$, range and $\pi \pm \mathrm{SD}$ ).

\begin{tabular}{|c|c|c|c|c|c|c|c|c|}
\hline & \multicolumn{8}{|c|}{ Species } \\
\hline & \multicolumn{2}{|c|}{ Palaemon northropi } & \multicolumn{2}{|c|}{ Palaemon pandaliformis } & \multicolumn{2}{|c|}{ Macrobrachium acanthurus } & \multicolumn{2}{|c|}{ Macrobrachium olfersii } \\
\hline & $\mathbf{M}$ & $\mathrm{F}$ & M & $\mathrm{F}$ & $\mathbf{M}$ & $\mathrm{F}$ & $\mathbf{M}$ & $\mathrm{F}$ \\
\hline $\begin{array}{l}\text { TBL (mm) } \\
\text { W (mg) }\end{array}$ & $\begin{array}{l}9.3-21.6 \\
2.7-54.0\end{array}$ & $\begin{array}{l}7.2-26.7 \\
0.9-126\end{array}$ & $\begin{array}{r}12.6-26.2 \\
6.9-62.0\end{array}$ & $\begin{array}{l}9.8-32.0 \\
3.0-110\end{array}$ & $\begin{array}{c}10.5-89.5 \\
4.0-5,772\end{array}$ & $\begin{array}{c}10.7-53.5 \\
4.1-808\end{array}$ & $\begin{array}{l}15.2-53.8 \\
15.2-1,659\end{array}$ & $\begin{array}{l}8.0-50.5 \\
1.9-1,093\end{array}$ \\
\hline $\begin{array}{c}\text { SOM (TBL, mm) } \\
(\mathrm{W}, \mathrm{mg})\end{array}$ & & $\begin{array}{l}21.1 \\
57.4\end{array}$ & & $\begin{array}{l}20.0 \\
27.3\end{array}$ & & $\begin{array}{r}29.7 \\
138.4\end{array}$ & & $\begin{array}{l}22.1 \\
67.0\end{array}$ \\
\hline $\begin{array}{l}\text { Egg size }(\mathrm{mm}) \\
\text { Egg W }(\mu \mathrm{g})\end{array}$ & & $\begin{array}{c}0.65 \times 0.48 \\
42\end{array}$ & & $\begin{array}{c}0.77 \times 0.63 \\
54\end{array}$ & & $\begin{array}{c}0.73 \times 0.57 \\
50\end{array}$ & & $\begin{array}{c}0.63 \times 0.51 \\
27\end{array}$ \\
\hline $\begin{array}{l}\text { Fecundity } \\
\text { RO (range, \%W) } \\
\quad(\quad \pm \text { SD) }\end{array}$ & & $\begin{array}{r}172-418 \\
8.9-19.3 \\
14.4 \pm 2.7\end{array}$ & & $\begin{array}{c}102-375 \\
12.6-24.5 \\
18.6 \pm 3.0\end{array}$ & & $\begin{array}{c}440-3,042 \\
13.5-30.0 \\
19.1 \pm 4.5\end{array}$ & & $\begin{array}{c}170-8,960 \\
6.9-38.4 \\
21.7 \pm 6.6\end{array}$ \\
\hline
\end{tabular}

\section{RESULTS}

\section{Body Size: Identification of Males and Onset of Female Reproduction}

Biometric data summarized for the four species of which we had the most material
(Palaemon northropi, P. pandaliformis, Macrobrachium acanthurus, $M$. olfersii; Table 1) include: observed range in total body length (TBL) and dry weight (W) of males and females (the latter including a few juveniles below the minimum sexable size, MSS), size at

Table 2. Palaemon northropi. Parameters of linear regressions (with or without preceding ln-transformation of dependent and independent variable, $Y, X)$ describing relationships between measurements of body size $(\mathrm{mm})$, weight (mg), and fecundity (egg number). TBL = total body length; $\mathrm{CL}=$ carapace length; $\mathrm{TL}=$ telson length; $\mathrm{W}=\mathrm{dry}$ weight; Fec = fecundity; $N=$ number of observations (data pairs); $r^{2}=$ coefficient of determination (ANOVA: all regression coefficients significantly different from zero, $P<0.001$, except for $\ln$ Fec regressed onto $\ln \mathrm{W}, P<0.01$; In Fec onto In TL not significant, n.s.). Morphometric and size-weight regressions computed separately for males (M) and females (F), Fec onto size or weight separately for early and late embryonic stages (St. I versus II and III combined); slopes statistically compared between sexes or embryonic stages (multiple ANCOVA); intercepts compared (after removal of the interaction term) when slopes were not significantly different from each other; levels of significance indicated with asterisks: ${ }^{*}, * *, * * *(P<0.05, P<0.01, P<0.001)$; regressions for pooled data $(\Sigma)$ given when neither the slope nor the intercept parameter differed significantly between sexes or stages, respectively.

\begin{tabular}{|c|c|c|c|c|c|c|}
\hline$Y$ & $x$ & Sex/stage & Intercept & Slope & $N$ & $r^{2}$ \\
\hline $\begin{array}{l}\text { TBL } \\
\ln \mathrm{TBL}\end{array}$ & $\begin{array}{l}\mathrm{CL} \\
\ln \mathrm{CL}\end{array}$ & $\begin{array}{l}\mathrm{M} \\
\mathrm{F} \\
\mathrm{M} \\
\mathrm{F}\end{array}$ & $\begin{array}{l}4.2260 * * * \\
2.8325 * * * \\
1.7729 * * * \\
1.6862 * * *\end{array}$ & $\begin{array}{l}3.2542 \\
3.3880 \\
0.7752 \\
0.8144\end{array}$ & $\begin{array}{l}48 \\
45 \\
48 \\
45\end{array}$ & $\begin{array}{l}0.8569 \\
0.9788 \\
0.8970 \\
0.9915\end{array}$ \\
\hline $\begin{array}{l}\text { TBL } \\
\ln \mathrm{TBL}\end{array}$ & $\begin{array}{l}\mathrm{TL} \\
\ln \mathrm{TL}\end{array}$ & $\stackrel{\Sigma}{\Sigma}$ & $\begin{array}{l}1.1442 \\
1.9241\end{array}$ & $\begin{array}{l}6.4380 \\
0.9965\end{array}$ & $\begin{array}{l}93 \\
93\end{array}$ & $\begin{array}{l}0.8853 \\
0.9265\end{array}$ \\
\hline $\begin{array}{l}\mathrm{CL} \\
\ln \mathrm{CL}\end{array}$ & $\begin{array}{l}\mathrm{TL} \\
\ln \mathrm{TL}\end{array}$ & $\begin{array}{l}M \\
F \\
M \\
F\end{array}$ & $\begin{array}{r}0.8063 \\
-0.3318 \\
0.5387 \\
0.2837\end{array}$ & $\begin{array}{l}1.3029 * \\
1.8636 * \\
0.9289 * \\
1.2350 *\end{array}$ & $\begin{array}{l}48 \\
45 \\
48 \\
45\end{array}$ & $\begin{array}{l}0.4976 \\
0.8698 \\
0.6009 \\
0.9368\end{array}$ \\
\hline $\ln W$ & $\ln \mathrm{TBL}$ & $\Sigma$ & -6.9903 & 3.5950 & 93 & 0.9663 \\
\hline $\ln W$ & $\ln C L$ & $\begin{array}{l}\mathrm{M} \\
\mathrm{F}\end{array}$ & $\begin{array}{l}-0.1300 \\
-0.9159\end{array}$ & $\begin{array}{l}2.4295^{*} \\
2.9394^{*}\end{array}$ & $\begin{array}{l}48 \\
45\end{array}$ & $\begin{array}{l}0.6946 \\
0.9716\end{array}$ \\
\hline $\ln W$ & $\ln \mathrm{TL}$ & $\begin{array}{l}\mathrm{M} \\
\mathrm{F}\end{array}$ & $\begin{array}{l}-0.5321 \\
-0.1551\end{array}$ & $\begin{array}{l}2.9205^{*} \\
3.6969^{*}\end{array}$ & $\begin{array}{l}48 \\
45\end{array}$ & $\begin{array}{l}0.9386 \\
0.9443\end{array}$ \\
\hline $\ln \mathrm{Fec}$ & $\ln \mathrm{TBL}$ & $\sum$ I-III & -2.9303 & 2.6958 & 25 & 0.5141 \\
\hline $\ln \mathrm{Fec}$ & $\ln C L$ & $\sum$ I-III & 2.1158 & 1.9163 & 25 & 0.3794 \\
\hline $\ln \mathrm{Fec}$ & $\ln T L$ & $\sum$ I-III & 4.6750 & 0.7639 & 25 & $0.1439^{\text {n.s. }}$ \\
\hline In Fec & $\ln W$ & $\sum$ I-III & 2.5643 & 0.6880 & 25 & 0.3501 \\
\hline
\end{tabular}


Table 3. Palaemon pandaliformis. Parameters of linear regressions (with or without preceding ln-transformation of dependent and independent variable, $Y, X)$ describing relationships between measurements of body size $(\mathrm{mm})$, weight (mg), and fecundity (egg number). TBL = total body length; $\mathrm{CL}=$ carapace length; $\mathrm{TL}=$ telson length; $\mathrm{W}=\mathrm{dry}$ weight; Fec = fecundity; $N=$ number of observations (data pairs); $r^{2}=$ coefficient of determination (ANOVA: all regression coefficients significantly different from zero, $P<0.001$ ). For further explanation see Table 2 .

\begin{tabular}{|c|c|c|c|c|c|c|}
\hline$Y$ & $x$ & Sex/stage & Intercept & Slope & $N$ & $r^{2}$ \\
\hline \multirow[t]{2}{*}{ TBL } & $\mathrm{CL}$ & $\mathbf{M}$ & 0.6198 & $4.4921^{*}$ & 35 & 0.9137 \\
\hline & & $\mathrm{F}$ & 1.9924 & $3.8652 *$ & 88 & 0.9444 \\
\hline \multirow[t]{2}{*}{$\ln \mathrm{TBL}$} & $\ln \mathrm{CL}$ & $\mathbf{M}$ & $1.5552 * * *$ & 0.9839 & 35 & 0.9447 \\
\hline & & $\mathrm{F}$ & $1.5751^{* * *}$ & 0.9222 & 88 & 0.9620 \\
\hline TBL & $\mathrm{TL}$ & $\Sigma$ & 2.6316 & 5.5340 & 123 & 0.9509 \\
\hline $\ln \mathrm{TBL}$ & $\ln \mathrm{TL}$ & $\bar{\Sigma}$ & 1.9505 & 0.9104 & 123 & 0.9670 \\
\hline \multirow[t]{2}{*}{$\mathrm{CL}$} & TL & $\mathbf{M}$ & $0.7047 * * *$ & 1.1618 & 35 & 0.8673 \\
\hline & & $\mathrm{F}$ & $0.4335^{* * *}$ & 1.3619 & 88 & 0.9154 \\
\hline \multirow[t]{2}{*}{$\ln C L$} & $\ln \mathrm{TL}$ & $\mathbf{M}$ & $0.4631 * * *$ & 0.8786 & 35 & 0.9163 \\
\hline & & $\mathrm{F}$ & $0.4426 * * *$ & 0.9591 & 88 & 0.9441 \\
\hline \multirow[t]{2}{*}{$\ln W$} & $\ln \mathrm{TBL}$ & $\mathbf{M}$ & $-5.7334 * * *$ & 3.0158 & 35 & 0.9796 \\
\hline & & $\mathbf{F}$ & $-5.7628 * * *$ & 3.0615 & 65 & 0.9754 \\
\hline \multirow[t]{2}{*}{$\ln W$} & $\ln \mathrm{CL}$ & $\mathbf{M}$ & $-1.1223^{* * *}$ & 3.0191 & 35 & 0.9580 \\
\hline & & $\mathrm{F}$ & $-0.9828 * * *$ & 2.8213 & 65 & 0.9711 \\
\hline \multirow[t]{2}{*}{$\ln W$} & $\ln \mathrm{TL}$ & $\mathbf{M}$ & $-0.1659 * *$ & 2.7429 & 35 & 0.9386 \\
\hline & & $\mathrm{F}$ & $-0.0742 * *$ & 2.9057 & 65 & 0.9516 \\
\hline $\ln \mathrm{Fec}$ & $\ln \mathrm{TBL}$ & $\sum \mathrm{I}-\mathrm{III}$ & -2.8787 & 2.5292 & 74 & 0.8695 \\
\hline $\ln \mathrm{Fec}$ & $\ln C L$ & $\sum$ I-III & 1.1543 & 2.3124 & 74 & 0.8489 \\
\hline $\ln \mathrm{Fec}$ & $\ln \mathrm{TL}$ & $\sum \mathrm{I}-\mathrm{III}$ & 2.4406 & 2.0387 & 74 & 0.8214 \\
\hline \multirow[t]{2}{*}{$\ln \mathrm{Fec}$} & $\ln W$ & Stage I & $2.2531 * *$ & 0.7511 & 23 & 0.7801 \\
\hline & & Stages II and III & $1.3392 * *$ & 0.9426 & 26 & 0.7632 \\
\hline
\end{tabular}

the onset of maturity (SOM, given as TBL and $\mathrm{W})$ in females, average size and $\mathrm{W}$ of early eggs, fecundity, and reproductive output (RO).

The minimum TBL or $\mathrm{W}$ in males represents the MSS of a species (with the possible exception of $M$. acanthurus, where no individuals smaller than the smallest identifiable males occurred). The MSS varied in these species between 9 and $15 \mathrm{~mm}$ TBL, without showing a correlation with the maximum size of the species. In Palaemon, the females grow to larger size than males, while the opposite is true for Macrobrachium. These differential patterns are reflected also in the maximum TBL and $\mathrm{W}$ measured in our material (Table 1).

The SOM of females may be related to the maximum size of a species. The greatest SOM (in terms of TBL) was found in the largest shrimp (M. acanthurus), the minimum occurred in the smallest species (P. northropi). However, the difference between the SOM in $M$. olfersii and in the much smaller species of Palaemonetes is almost negligible. SOM, expressed as W, increases in the same order, but with clearer interspecific differences: $P$. pandaliformis $<P$. northropi $<M$. olfersii $<$ M. acanthurus (Table 1).

\section{Morphometrics: Relationships between Size Dimensions}

In all four species for which we had sufficient material, we found significant correlations among different measurements of body size (TBL, CL, TL; Tables 2-5). Similar relationships were found in Potimirim potimirim (Table 6). Allometric functions consistently provided a better fit for morphometric relationships than did linear functions. This is indicated by higher coefficients of determination, $r^{2}$, after logarithmic transformation of both the $X$ and $Y$ values (only exception: TBL versus CL in male $M$. acanthurus). Thus, these relationships indicate allometric growth in different parts of the body. We give here, however, the parameters of both the linear and power functions to allow comparisons with other data from the literature, which include various models. All morphometric regressions were calculated separately for males and females; pooled regressions are given only where differences between the slopes or intercepts of separate regressions were statistically not significant. Significant differences indicate sex-specific differences in al- 
Table 4. Macrobrachium acanthurus. Parameters of linear regressions (with or without preceding ln-transformation of dependent and independent variable, $Y, X)$ describing relationships between measurements of body size (mm), weight (mg), and fecundity (egg number). $\mathrm{TBL}=$ total body length; $\mathrm{CL}=$ carapace length; $\mathrm{TL}=$ telson length; $\mathrm{W}=$ dry weight; Fec = fecundity; $N=$ number of observations (data pairs); $r^{2}=$ coefficient of determination (ANOVA: all regression coefficients significantly different from zero, $P<0.001$ ). For further explanation see Table 2 .

\begin{tabular}{|c|c|c|c|c|c|c|}
\hline$Y$ & $x$ & Sex/stage & Intercept & Slope & $N$ & $r^{2}$ \\
\hline \multirow[t]{2}{*}{ TBL } & \multirow[t]{2}{*}{$\mathrm{CL}$} & $\mathbf{M}$ & 7.3949 & $2.6711 * * *$ & 66 & 0.9843 \\
\hline & & $\mathrm{F}$ & 4.3201 & $2.9428 * * *$ & 89 & 0.9649 \\
\hline \multirow[t]{2}{*}{$\ln \mathrm{TBL}$} & \multirow[t]{2}{*}{$\ln \mathrm{CL}$} & $\mathbf{M}$ & 1.7923 & $0.7659 * *$ & 66 & 0.9673 \\
\hline & & $\mathrm{F}$ & 1.6147 & $0.8304^{* *}$ & 89 & 0.9786 \\
\hline \multirow{3}{*}{$\begin{array}{l}\text { TBL } \\
\ln \mathrm{TBL}\end{array}$} & \multirow{3}{*}{$\begin{array}{l}\mathrm{TL} \\
\ln \mathrm{TL}\end{array}$} & $\Sigma$ & -0.0120 & 6.2506 & 155 & 0.9222 \\
\hline & & $\mathbf{M}$ & 1.9421 & $0.9132 * *$ & 66 & 0.9437 \\
\hline & & $\mathrm{F}$ & 1.8202 & $1.0117 * *$ & 89 & 0.9493 \\
\hline \multirow[t]{2}{*}{$\mathrm{CL}$} & \multirow[t]{2}{*}{ TL } & $\mathbf{M}$ & $-2.5244 * *$ & 2.2440 & 66 & 0.8986 \\
\hline & & $\mathrm{F}$ & $-1.3131 * *$ & 2.1166 & 89 & 0.9183 \\
\hline \multirow[t]{2}{*}{$\ln C L$} & \multirow[t]{2}{*}{$\ln T L$} & $\mathbf{M}$ & $0.2287 * * *$ & 1.1690 & 66 & 0.9377 \\
\hline & & $\mathrm{F}$ & $0.2720 * * *$ & 1.2019 & 89 & 0.9442 \\
\hline \multirow[t]{2}{*}{$\ln W$} & \multirow[t]{2}{*}{$\ln \mathrm{TBL}$} & M & -6.7847 & $3.4202 * *$ & 66 & 0.9806 \\
\hline & & $\mathrm{F}$ & -5.8806 & $3.1678 * *$ & 89 & 0.9742 \\
\hline \multirow[t]{2}{*}{$\ln W$} & \multirow[t]{2}{*}{$\ln \mathrm{CL}$} & $\mathbf{M}$ & $-0.7102 *$ & 2.6489 & 66 & 0.9700 \\
\hline & & $\mathrm{F}$ & $-0.8258^{*}$ & 2.6596 & 89 & 0.9744 \\
\hline \multirow[t]{2}{*}{$\ln W$} & \multirow[t]{2}{*}{$\ln T L$} & $\mathbf{M}$ & $-0.1596^{*}$ & 3.1357 & 66 & 0.9326 \\
\hline & & $\mathrm{F}$ & $-0.1198^{*}$ & 3.2084 & 89 & 0.9268 \\
\hline $\ln \mathrm{Fec}$ & $\ln \mathrm{TBL}$ & $\sum$ I-III & -3.6715 & 2.8994 & 29 & 0.7603 \\
\hline $\ln \mathrm{Fec}$ & $\ln \mathrm{CL}$ & $\sum$ I-III & 0.4367 & 2.6555 & 29 & 0.7188 \\
\hline $\ln \mathrm{Fec}$ & $\ln \mathrm{TL}$ & $\sum$ I-III & 2.1739 & 2.6210 & 29 & 0.6249 \\
\hline \multirow[t]{2}{*}{$\ln \mathrm{Fec}$} & \multirow[t]{2}{*}{$\ln W$} & Stage I & $0.9830 *$ & 1.0636 & 17 & 0.7942 \\
\hline & & Stages II and III & $0.5706^{*}$ & 1.1012 & 12 & 0.8461 \\
\hline
\end{tabular}

lometric growth and, thus, reflect sexual dimorphism. Since we consider differences between slopes as biologically more meaningful than those between intercepts alone (see below, Discussion), we describe only the former cases.

In $P$. northropi, different slopes were observed only in the relationship between CL and $T L$, indicating that the $C L$ increases in females proportionally faster in relation to TL than in males. In $P$. pandaliformis, significantly different slopes in the linear relationship between TBL and CL suggest that male TBL increases during growth in relation to $\mathrm{CL}$ at a faster rate than in females. An opposite tendency was observed in species of Macrobrachium. The size data showed here a significantly higher slope in the regressions of TBL on CL in females.

\section{Size-Weight Relationships}

When size-weight relationships are compared among different species or sexes, inter- and intraspecific differences in the sizedependence of weight can be detected. In a comparison of male and female P. northropi, statistically significant differences were found between the slopes of the regressions $\mathrm{W}$ on $\mathrm{CL}$ or TL. In both species of Palaemon, the increase in W with increasing TBL was steeper in females than in males (Fig. 1a; but not significant statistically in $P$. northropi; Table 2). Likewise, the dependence of $W$ on TBL differed significantly between sexes in both species of Macrobrachium, but with an opposite pattern (Fig. 1b). These differential sex-specific patterns appear to reflect generic differences in sexual dimorphism.

Among the species studied, P. northropi showed on the average the steepest slope in the regression $\mathrm{W}$ on TBL, $P$. pandaliformis the smallest, and the two species of Macrobrachium as well as Potimirim potimirim were intermediate (Tables 2-6). The few measurements obtained from $M$. carcinus suggest that this species shows a size-weight relationship similar to that of $M$. acanthurus.

\section{Size-Specific Fecundity}

In all species for which we had sufficient data, realized fecundity showed significant relationships with all measurements of body 
Table 5. Macrobrachium olfersii. Parameters of linear regressions (with or without preceding ln-transformation of dependent and independent variable, $Y, X)$ describing relationships between measurements of body size $(\mathrm{mm})$, weight (mg), and fecundity (egg number). $\mathrm{TBL}=$ total body length; $\mathrm{CL}=$ carapace length; $\mathrm{TL}=$ telson length; $\mathrm{W}=\mathrm{dry}$ weight; Fec = fecundity; $N=$ number of observations (data pairs); $r^{2}=$ coefficient of determination (ANOVA: all regression coefficients significantly different from zero, $P<0.001$ ). For further explanation see Table 2 .

\begin{tabular}{|c|c|c|c|c|c|c|}
\hline$Y$ & $x$ & Sex/stage & Intercept & Slope & $N$ & $r^{2}$ \\
\hline $\begin{array}{l}\text { TBL } \\
\ln \mathrm{TBL}\end{array}$ & $\begin{array}{l}\mathrm{CL} \\
\ln \mathrm{CL}\end{array}$ & $\begin{array}{l}\text { M } \\
\text { F } \\
\mathbf{M} \\
\mathbf{F}\end{array}$ & $\begin{array}{l}6.7152 \\
3.0066 \\
1.5892 \\
1.5131\end{array}$ & $\begin{array}{l}2.3601 * * * \\
2.7877 * * * \\
0.7947 * \\
0.8378 *\end{array}$ & $\begin{array}{l}42 \\
77 \\
42 \\
77\end{array}$ & $\begin{array}{l}0.9808 \\
0.9912 \\
0.9832 \\
0.9946\end{array}$ \\
\hline $\begin{array}{l}\text { TBL } \\
\ln \mathrm{TBL}\end{array}$ & $\begin{array}{l}\mathrm{TL} \\
\ln \mathrm{TL}\end{array}$ & $\begin{array}{l}\text { M } \\
\text { F } \\
M \\
F\end{array}$ & $\begin{array}{r}-0.3077^{* * *} \\
-1.3013^{* * *} \\
1.8331^{* * *} \\
1.8020^{* * *}\end{array}$ & $\begin{array}{l}6.5690 \\
7.1252 \\
1.0230 \\
1.0752\end{array}$ & $\begin{array}{l}42 \\
77 \\
42 \\
77\end{array}$ & $\begin{array}{l}0.9602 \\
0.9599 \\
0.9697 \\
0.9828\end{array}$ \\
\hline $\begin{array}{l}\mathrm{CL} \\
\ln \mathrm{CL}\end{array}$ & $\begin{array}{l}\mathrm{TL} \\
\ln \mathrm{TL}\end{array}$ & $\sum$ & $\begin{array}{r}-1.6790 \\
0.3584\end{array}$ & $\begin{array}{l}2.5703 \\
1.2670\end{array}$ & $\begin{array}{l}119 \\
119\end{array}$ & $\begin{array}{l}0.9531 \\
0.9780\end{array}$ \\
\hline $\ln W$ & $\ln \mathrm{TBL}$ & $\begin{array}{l}\text { M } \\
\mathrm{F}\end{array}$ & $\begin{array}{l}-7.1200 \\
-6.1783\end{array}$ & $\begin{array}{l}3.5971^{*} \\
3.3230^{*}\end{array}$ & $\begin{array}{l}42 \\
77\end{array}$ & $\begin{array}{l}0.9293 \\
0.9877\end{array}$ \\
\hline $\ln W$ & $\ln C L$ & $\Sigma$ & -1.1646 & 2.7794 & 119 & 0.9724 \\
\hline $\ln W$ & $\ln \mathrm{TL}$ & $\begin{array}{l}\text { M } \\
\text { F }\end{array}$ & $\begin{array}{l}-0.5086^{* *} \\
-0.1840^{* *}\end{array}$ & $\begin{array}{l}3.6694 \\
3.5683\end{array}$ & $\begin{array}{l}42 \\
77\end{array}$ & $\begin{array}{l}0.8960 \\
0.9682\end{array}$ \\
\hline $\ln \mathrm{Fec}$ & ln TBL & $\begin{array}{l}\text { Stage I } \\
\text { Stages II and III }\end{array}$ & $\begin{array}{l}-7.1847 * * \\
-4.1974 * *\end{array}$ & $\begin{array}{l}4.1710 \\
3.2367\end{array}$ & $\begin{array}{l}23 \\
26\end{array}$ & $\begin{array}{l}0.8721 \\
0.6250\end{array}$ \\
\hline $\ln \mathrm{Fec}$ & $\ln C L$ & $\begin{array}{l}\text { Stage I } \\
\text { Stages II and III }\end{array}$ & $\begin{array}{r}-1.2541^{*} \\
0.4705^{*}\end{array}$ & $\begin{array}{l}3.6294 \\
2.8167\end{array}$ & $\begin{array}{l}23 \\
26\end{array}$ & $\begin{array}{l}0.7143 \\
0.5887\end{array}$ \\
\hline ln Fec & $\ln T L$ & $\begin{array}{l}\text { Stage I } \\
\text { Stages II and III }\end{array}$ & $\begin{array}{l}0.6595 * * \\
1.8959 * *\end{array}$ & $\begin{array}{l}4.3252 \\
3.3493\end{array}$ & $\begin{array}{l}23 \\
26\end{array}$ & $\begin{array}{l}0.7388 \\
0.6126\end{array}$ \\
\hline $\ln \mathrm{Fec}$ & $\ln W$ & $\begin{array}{l}\text { Stage I } \\
\text { Stages II and III }\end{array}$ & $\begin{array}{l}0.1670 * * * \\
1.8206 * * *\end{array}$ & $\begin{array}{l}1.3382 \\
0.9655\end{array}$ & $\begin{array}{l}23 \\
26\end{array}$ & $\begin{array}{l}0.8592 \\
0.6280\end{array}$ \\
\hline
\end{tabular}

size (Tables 2-5). As an exception, the regression of egg number on telson length (TL) was in $P$. northropi not significant statistically. In this species, the size range of ovigerous females was very small. Consequently, fecundity showed only weak correlations with size or W. Moreover, TL showed in general the lowest correlations with other biometric data. Fecundity in terms of total egg mass can easily be obtained by multiplication of the initial egg weight in a given species (Table 1) with the regressions for egg number on female body size.

In comparison with all other species, $M$.

Table 6. Potimirim potimirim. Parameters of linear regressions (with or without preceding ln-transformation of dependent and independent variable, $Y, X$ ) describing relationships between measurements of body size ( $\mathrm{mm}$ ), and weight (mg). TBL = total body length; $\mathrm{CL}=$ carapace length; $\mathrm{TL}=$ telson length; $\mathrm{W}=$ dry weight; $N=$ number of observations (data pairs); $r^{2}=$ coefficient of determination (ANOVA: all regression coefficients significantly different from zero, $P<0.001)$. For further explanation see Table 2 .

\begin{tabular}{lllll}
\hline \multicolumn{1}{c}{$Y$} & \multicolumn{1}{c}{$X$} & Intercept & Slope & $r^{2}$ \\
\hline TBL & CL & 1.3952 & 3.1252 & 0.9416 \\
$\ln$ TBL & $\ln \mathrm{CL}$ & 1.3301 & 0.9380 & 0.9735 \\
TBL & TL & 0.3871 & 7.5257 & 0.9518 \\
$\ln$ TBL & $\ln \mathrm{TL}$ & 2.0442 & 0.9993 & 0.9776 \\
CL & TL & -0.0215 & 2.2532 & 0.8850 \\
$\ln \mathrm{CL}$ & $\ln \mathrm{TL}$ & 0.7806 & 1.0347 & 0.9471 \\
$\ln \mathrm{W}$ & $\ln \mathrm{TBL}$ & -5.9250 & 3.2357 & 0.9798 \\
$\ln \mathrm{W}$ & $\ln \mathrm{CL}$ & -1.6524 & 3.0568 & 0.9675 \\
$\ln \mathrm{W}$ & $\ln \mathrm{TL}$ & 0.7106 & 3.1999 & 0.9380 \\
\hline
\end{tabular}



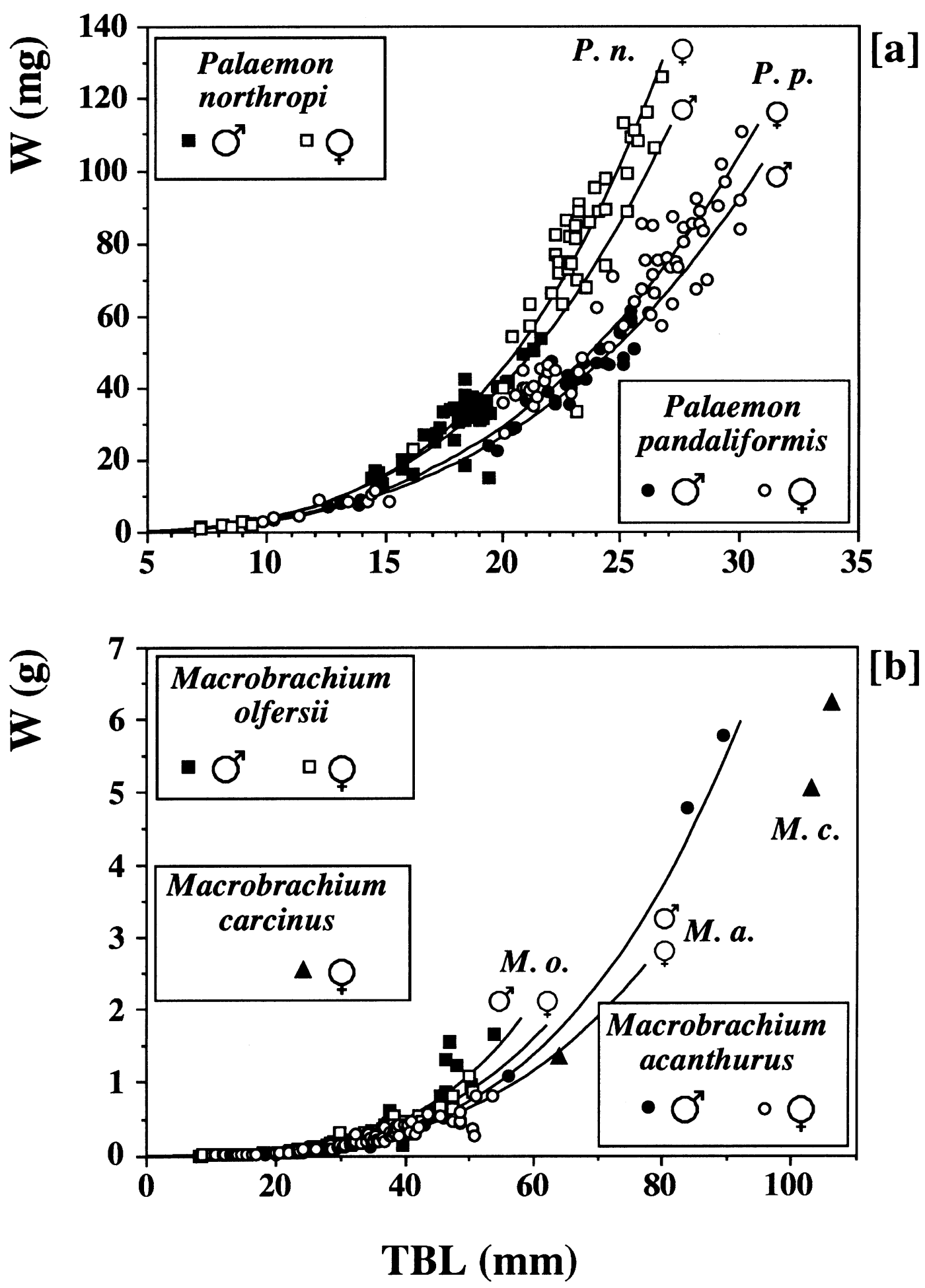

Fig. 1. Allometric relationship between total body length (TBL, mm) and dry weight (W, $\mathrm{mg}$ or $\mathrm{g}$ ) in males and females of (a) Palaemon northropi (P.n.), P. pandaliformis (P.p.), (b) Macrobrachium acanthurus (M.a.), M. olfersii (M.o.); three occasional measurements from M. carcinus (M.c.) included; for fitted parameters of regression equations see Tables $2-5$. 

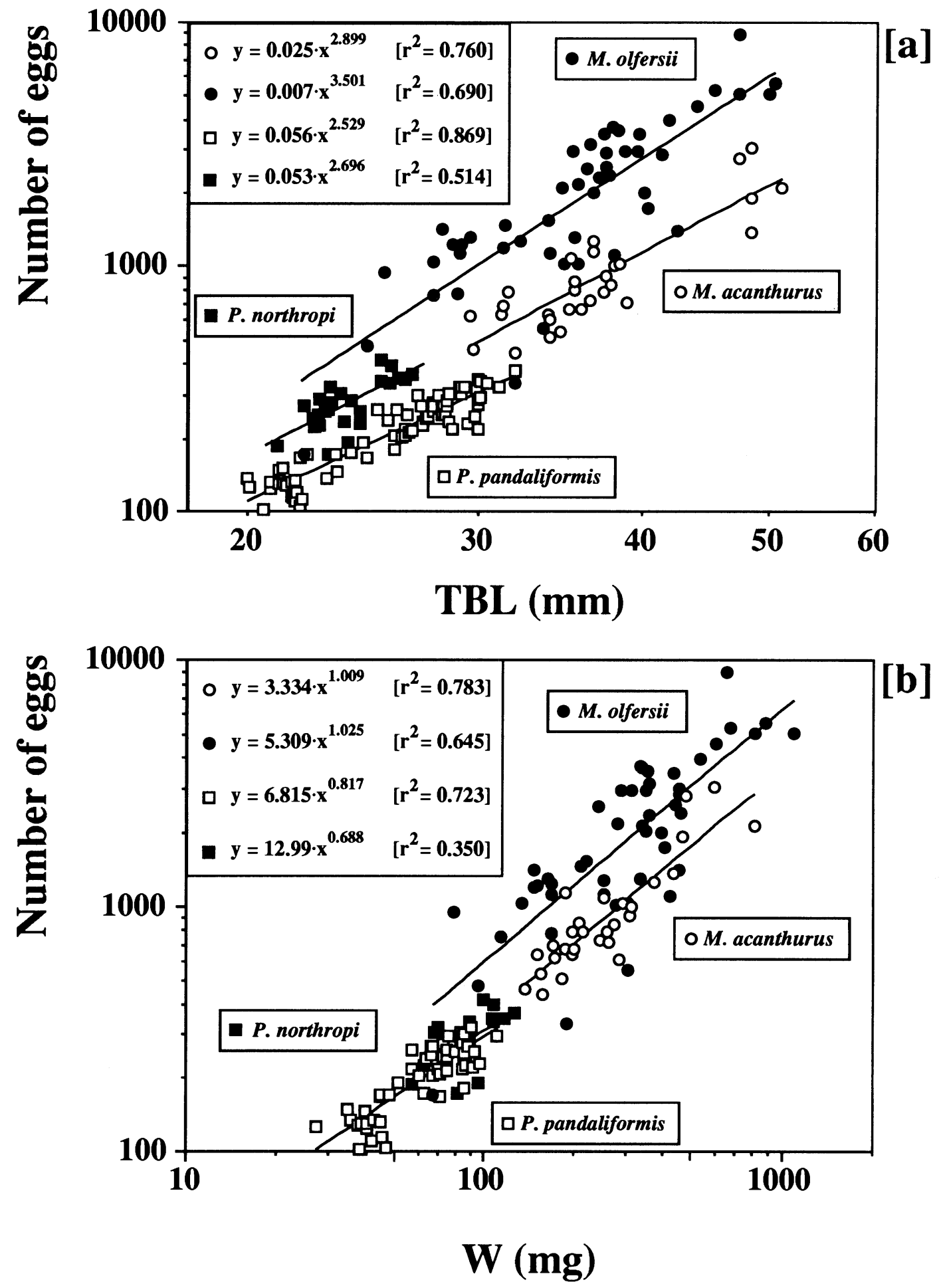

Fig. 2. Relationship between fecundity (number of eggs, pooled data of all developmental stages) and (a) total body length (TBL, mm), (b) female dry weight (W, mg), in: Palaemon northropi, $P$. pandaliformis; Macrobrachium acanthurus, $M$. olfersii; allometric regression equations and coefficients of determination, $r^{2}$, given in graphs; for fitted parameters of regression equations calculated separately for eggs in early and late stages of development see Tables 2-5; graphic presentation of regressions linearized by $\ln$-ln-transformation. 
olfersii showed a stronger dependence of fecundity on size (TBL), as indicated by a significantly steeper slope parameter $(P<0.05)$. In addition, our regressions showed speciesspecific differences in the overall level of egg production. A comparison of pooled data of fecundity in $M$. acanthurus and $P$. northropi (these regressions were not significantly different) with those in $P$. pandaliformis showed a highly significant difference between the intercepts. This indicates an almost parallel shift of regression lines, i.e., differential fecundity at equal female size (Fig. $2 \mathrm{a} ; P<$ 0.001 ). Among the species studied, $M$. olfersii showed the highest level of size-specific fecundity, $P$. pandaliformis the lowest.

These patterns change when fecundity is considered in relation to body $\mathrm{W}$ rather than TBL (Fig. 2b), reflecting species-specific differences in the size-weight relationships. The slopes of the regressions of egg number on $\mathrm{W}$ were similar in all species, without statistically significant differences. As in the relationship between egg number and TBL (cf. Fig. 2a), the overall level of fecundity in relation to female $\mathrm{W}$ was significantly higher in $M$. olfersii than in all other species (pooled data; differences between intercepts, $P<$ 0.001 ). No significant interspecific differences between slopes or intercepts occurred among the other species.

Only three ovigerous females of $M$. carcinus were caught $(64,103$, and 106-mm TBL; $1.352,5.057$, and $6.2214 \mathrm{~g} \mathrm{~W}$ ), carrying $16,100,34,500$, and 50,300 eggs, respectively. These data fit well into the relationships between fecundity and female size or $\mathrm{W}$ in $M$. acanthurus. In our material of the atyid shrimp Potimirim potimirim, a small number of observations $(N=8)$ and a narrow size range of ovigerous females (16.118.1-mm TBL) did not allow for calculating regressions of fecundity on other biometric data. The number of eggs per female varied in this species between 103 and $410(\bar{x} \pm$ SD $=247 \pm 91$ ).

\section{Egg Size and Reproductive Output (RO)}

Initial values of egg size and $\mathrm{W}$ were lowest in $M$. olfersii, highest in $P$. pandaliformis (Table 1). These life-history parameters did not show a relationship with the genus, the maximum size, or the ecology of the species.

When egg production (expressed as $\mathrm{W}$ of the entire egg mass) is considered in relation to the $\mathrm{W}$ of ovigerous females, the reproductive output (RO) is obtained (Table 1). On the average, this was significantly lower in the only marine shrimp studied here, $P$. northropi, than in the three fresh-water species $(P<0.01)$. The highest values were observed in species of Macrobrachium. The mean RO in $M$. olfersii was also significantly higher than in $P$. pandaliformis $(P<0.05)$. In $M$. olfersii, the RO was significantly influenced by female body size (TBL), tending to increase in larger females (ANCOVA; $P<0.01)$. By contrast, no significant dependence on female size or weight could be detected in the other species.

\section{DISCUSSION}

\section{Size at the Onset of Maturity (SOM) and} Minimum Sexable Size (MSS)

Size at the onset of maturity (SOM) is considered as a key life-history parameter that should reflect also the longevity and life-time investment in reproduction of a species. In all species studied here, the minimum size of ovigerous females (Table 1) was considerably below that reported in the literature (Holthuis, 1952; Gomes Corrêa, 1977; Lobão, 1977), suggesting that our data represent a fair approximation of their actual SOM. In both species of Palaemon, these values were surprisingly similar to those in a much larger shrimp, $M$. olfersii, suggesting a poor correlation with the maximum size of the species. However, size at the onset of egg production may vary among conspecific populations (Wenner et al., 1985).

The comparability of SOM in different species is increased when it is given as a relative number, the RSOM. This is calculated as the quotient of SOM in relation to maximum body size in a species; this is estimated as parameter $\mathrm{L}_{\infty}$ of the von Bertalanffy equation of growth (Charnov, 1990). In decapod taxa with a terminal molt (e.g., majid crabs; Hartnoll, 1985), the RSOM is identical with the maximum size (RSOM $=100 \%$ ). Other taxa continue to molt after reaching sexual maturity, but often with little additional growth. In the shrimp family Pandalidae, Charnov (1990) observed a rather constant RSOM of approximately 55\%, regardless of the species or latitude, and suggested that this might be a more generally applicable number in the Crustacea. When female SOM values from the present study are related to max- 
imum body size of females in the species studied, an estimate of their RSOM is obtained. Since our material was not representative of overall size range, we may use data from the literature. According to Sawaya (1946), Holthuis (1952), and Gomes Corrêa (1977), maximum female size of about 44 mm TBL may be assumed for $P$. northropi, $43 \mathrm{~mm}$ for $P$. pandaliformis, $65 \mathrm{~mm}$ for $M$. olfersii, and $110 \mathrm{~mm}$ for $M$. acanthurus. From these data, RSOM values of $48,46,34$, and $27 \%$, respectively, are calculated for these species of shrimps.

These figures indicate a greater interspecific variability than assumed by Charnov (1990), and all are well below the 55\% suggested as a possible biological rule. This indicates that the onset of female maturity may occur early within the life cycle of caridean shrimps. In fact, their actual RSOM might be even smaller, because the maximum size reported in the literature is only an approximation of the theoretical maximum, $\mathrm{L}_{\infty}$, and the possible minimum size of ovigerous females may still be smaller than in our material. On the other hand, our estimates may be biased due to geographic variation in both SOM and maximum size. If our estimates are correct, the RSOM is, in the species studied, inversely correlated with maximum body size.

As another life-history parameter, the minimum sexable size (MSS) has practical value. We defined it here as the minimum body size of males with a developed appendix masculina. This is not necessarily identical with male SOM, but it allows for sex separation in studies of population structure. The MSS was surprisingly similar in the species studied (Table 1). As a percentage of the maximum TBL reported for males (Sawaya, 1946; Holthuis, 1952; Gomes Corrêa, 1977), the MSS was reached with $28,33,6$, and $17 \%$ in $P$. northropi, $P$. pandaliformis, $M$. acanthurus, and $M$. olfersii, respectively. Since no unsexable juveniles occurred in our material of $M$. acanthurus, the actual MSS of this species might be even smaller than $6 \%$ of maximum male size.

\section{Morphometric Relationships among Size Dimensions}

In all species studied, statistically significant sex-specific differences were observed in the morphometric relationships among different dimensions of body size. However, dif- ferent intercepts are difficult to interpret, because this parameter may represent an extrapolation below the range measured, and its comparison may have little biological meaning. By contrast, the slope should be a more useful growth parameter, indicating a different degree of dependence among size dimensions. For intra- and interspecific comparisons, however, the same regression model must be used. In our study, the model with the best fit (highest $r^{2}$ ) was almost consistently an allometric function (linear after log$\log$ transformation). On the other hand, a linear model has also been used in the literature, and to facilitate comparisons, we give linear regressions.

In agreement with the literature, our data show that carapace length is a reliable measurement of the total body size of shrimps. When the relationships between TBL and CL in the species studied are described with the allometric model, the slope parameter is similar to that in other palaemonid shrimps (Wickins, 1972), while higher values were reported for penaeids (Kutkuhn, 1966; Rodríguez, 1987). This may indicate a difference in growth characteristics of caridean and penaeid shrimps. However, when the linear model is applied, the slope of this relationship varied in our study within the same range as reported for several species of both caridean (Shafi et al., 1977; Shumway et al., 1985; Rodrigues Capitulo and Freyre, 1989; Gabche and Hockey, 1995) and penaeid shrimps (Farmer, 1986; Dall et al., 1990). Not enough data are available to allow for generalizations of morphometric patterns in shrimps, in particular with regard to sexual dimorphism in the proportions of CL and TBL. The available data do not show a relationship of these traits with geographic origin, climate, or ecology of the species.

Since telson length (TL) has been used very little as a measure of body size, no interspecific comparisons with literature data from other palaemonid shrimps are possible. Our data show that TL is a fairly good predictor of TBL or CL, although its relatively small size, individual variability, and difficulties in its measurement (e.g., including versus excluding terminal spines) cause high residual errors in regressions on other size dimensions, weight, or fecundity. We suggest that TL should be measured in cases where restricted quantities of live material are available, re- 
Table 7. Slope parameters of the allometric size-weight relationship (linear after $\ln$-ln transformation of size and weight data) in several palaemonid and one atyid shrimp species; given separately for males and females, where data are available; otherwise for pooled data, $\Sigma$; size measured as total body length (mm; except for Hartnoll and Salama, 1992: carapace length, $\mathrm{mm})$; weight as fresh or dry weight $(\mathrm{FW}, \mathrm{W}, \mathrm{mg}) ; *=$ M. olfersii (Holthuis, personal communication).

\begin{tabular}{|c|c|c|c|c|c|c|}
\hline \multirow[b]{2}{*}{ Species } & \multicolumn{3}{|c|}{ Slope } & \multirow[b]{2}{*}{ Size } & \multirow[b]{2}{*}{ Weight } & \multirow[b]{2}{*}{ Reference } \\
\hline & Males & $\Sigma$ & Females & & & \\
\hline Palaemon northropi Rankin & 3.29 & & 3.61 & TBL & W & present study \\
\hline P. pandaliformis Stimpson & 3.02 & & 3.06 & TBL & W & present study \\
\hline P. xiphias Risso & 2.97 & & 3.14 & TBL & FW & Guerao et al. (1994) \\
\hline P. paucidens de Haan & 3.07 & & 3.20 & TBL & FW & Ogawa and Kakuda (1988) \\
\hline P. elegans Rathke & & 2.82 & & $\mathrm{CL}$ & $\mathbf{W}$ & Hartnoll and Salama (1992) \\
\hline P. serratus Pennant & & 3.76 & & TBL & W & Reeve (1969) \\
\hline Palaemonetes argentinus Nobili & 3.04 & & 3.34 & TBL & FW & Donatti (1986) \\
\hline Macrobrachium acanthurus Wiegmann & 3.42 & & 3.17 & TBL & W & present study \\
\hline M. olfersii Wiegmann & 3.60 & & 3.32 & TBL & W & present study \\
\hline M. holthuisi Genofre and Lobão* & 3.38 & & 2.58 & TBL & FW & Lobão (1977) \\
\hline M. völlenhovenii Herklots & 2.88 & & 2.92 & TBL & FW & Gabche and Hockey (1995) \\
\hline M. völlenhovenii Herklots & & 3.32 & & TBL & FW & Willführ-Nast et al. (1993) \\
\hline M. rosenbergii de Man & & 3.23 & & TBL & FW & Wickins (1972) \\
\hline M. rosenbergii de Man & & 3.36 & & TBL & FW & Kuris et al. (1987) \\
\hline M. lamarrei Edwards & & 3.53 & & TBL & FW & Shafi et al. (1977) \\
\hline M. mirabilis Kemp & & 2.68 & & TBL & FW & Shafi et al. (1977) \\
\hline Potimirim potimirim Müller & & & 3.24 & TBL & W & present study \\
\hline
\end{tabular}

quiring nondestructive sampling procedures, e.g., size measurements in cast exuviae. In such materials, it is usually impossible to measure TBL, and that of CL may be difficult, because the carapace tends to be deformed in shrimp exuviae.

\section{Size-Weight Relationships}

The allometric relationship between size and weight is consistently described in the literature with a power function (Kurata, 1962; Hartnoll, 1985). The logarithmic transformation of size and weight data "is necessary in order to conform more closely to the assumptions of linear regression analysis regarding homogeneity of error variance over the range of the equation" (Bird and Prairie, 1985). While the intercept depends strongly on the dimension of size measured in a particular study, the slope should be more independent of this and other methodological details. An interspecific comparison of slope parameters of size-W relationships in shrimps is given in Table 7. Among these species, variation in the slope appears to be unrelated to the generic or family position, and to the specific ecology or geographic origin.

Sex-specific differences in this relationship were observed in the species studied (only in $P$. northropi not significant statistically), and in numerous other caridean and penaeid shrimps (Lobão, 1977; Donatti, 1986; Rodríguez, 1987; Ogawa and Kakuda, 1988; Dall et al., 1990). In species of Palaemon and Palaemonetes, a higher slope was consistently observed in females, while species of Macrobrachium show the opposite tendency (with the possible exception of $M$. völlenhovenii Herklots; Table 7). The faster weight gain in relation to TBL in female Palaemon and species of Palaemonetes may be caused by proportionally greater tissue production in the ovaries compared with that in the testes. This effect should occur also in species of Macrobrachium, but here it may be overcompensated for by stronger sexual dimorphism in other organs, namely, by disproportionate growth of chelae in large males.

\section{Size-Specific Fecundity}

The relationship between female size and egg number is usually described as an allometric function equivalent to that between size and weight (Hartnoll, 1985; Somers, 1991), although linear regressions have also been used (e.g., Shumway et al., 1985; Corey, 1991; Corey and Reid, 1991). Furthermore, fecundity has been described as a function of female carapace volume (Corey and Reid, 1991; Reid and Corey, 1991) or body weight (Clarke, 1993; present study). Since an allometric function is the most commonly used model of size-specific fecundity, the slope parameter of the linearized regression equation (ln egg number regressed on $\ln$ TBL or CL) may be compared among species or popula- 
Table 8. Slope parameters of the allometric size-fecundity relationship (after $\ln -\ln$ transformation of size and egg numbers) in several palaemonid shrimp species; size measured as total body length (mm; except for Yan, 1987; Bauer, 1991: carapace length).

\begin{tabular}{lcll}
\hline \multicolumn{1}{c}{ Species } & Slope & \multicolumn{1}{c}{ Habitat } & \multicolumn{1}{c}{ Reference } \\
\hline Palaemon northropi Rankin & 2.70 & marine & present study \\
P. pacificus Stimpson & 2.60 & marine & Emmerson (1985) \\
P. xiphias Risso & 3.59 & marine & Guerao et al. (1994) \\
P. elegans Rathke & 2.57 & marine-estuarine & Hoglund (1943); Somers (1991) \\
P. pandaliformis Stimpson & 2.53 & freshwater-estuarine & present study \\
P. paucidens de Haan & $2.26-2.78$ & freshwater & Mashiko (1982); Ogawa \\
& & & and Kakuda (1988) \\
Palaemonetes pugio Holthuis & 2.62 & estuarine & Yan (1987) \\
P. vulgaris Say & 2.37 & estuarine & Yan (1987) \\
Leander tenuicornis Say & 3.17 & marine & Bauer (1991) \\
Periclimenes americanus Kingsley & 3.28 & marine & Bauer (1991) \\
Macrobrachium acanthurus Wiegmann & 2.90 & freshwater & present study \\
M. olfersii Wiegmann & 4.17 & freshwater & present study \\
M. nippoense de Haan & $2.68-4.02$ & estuarine-freshwater & Mashiko (1983, 1990) \\
M. amazonicum Heller & 0.93 & freshwater & Collart (1991) \\
\hline
\end{tabular}

tions (Table 8). In our study, this index varied between 2.6 and 2.7 in species of Palaemon, and from 2.9 to 4.2 in species of $\mathrm{Mac}$ robrachium. Among other palaemonid species, the size-dependence of fecundity varies without showing a relationship with the habitat of the adult population (fresh water, brackish water, or marine; cf. Corey and Reid, 1991; Reid and Corey, 1991); it appears to be particularly strong in $M$. olfersii.

Significantly different intercepts (i.e., parallel shifts) in fecundity-size regressions, by contrast, seem to be related to different habitats. In palaemonid shrimps from Japan, both intra- and interspecific variation were shown in the overall level of fecundity (Mashiko, 1982, 1983, 1990). Fresh-water populations tend to produce a smaller number of larger eggs, whereas those living in estuaries produce more but smaller eggs. In the present study, the fresh-water species $P$. pandaliformis showed a significantly lower level of size-specific fecundity than the marine congener $P$. northropi. However, when fecundity was regressed on W rather than TBL, similar relations were obtained in these ecologically different species of Palaemon. The two species of Macrobrachium, which live together in the same habitat, differed greatly in this respect (Fig. 2). This demonstrates that these life-history traits may be affected by methodological details, and that they may be more related to taxonomic position than to climatic variables.

To make intercept parameters universally comparable among literature data, and thus, to identify possible relationships between size-specific fecundity and habitat conditions, a standardization of size and weight measurements is necessary. Since the length of spines on the rostrum and telson may vary considerably among species, even among individuals, we suggest that measurements of CL and TBL be taken from the rear margin of the eye orbit rather than from the tip of the rostral spine. The rear margin of the telson (without terminal spines) should define the posterior mark for measurements of body size. Moreover, we suggest the general use of the allometric model for regressions of fecundity on size or weight, since this is analytically simple and independent of the relative scale (for discussion of various models, see Somers, 1991).

\section{Egg Loss}

While the number of freshly laid eggs per female represents its "realized reproduction," the number of eggs in late stages of development is closer to the "actual reproduction," i.e., the number of larvae produced (Corey, 1991). The latter is lower, due to various causes of brood mortality (Kuris, 1991; Lardies and Wehrtmann, 1996; Ohtomi, 1997). Egg loss is thus another life-history parameter that can be compared among species, populations, size groups, or habitats. Quantitative estimates are possible when size- or weight-specific fecundity is compared between egg clutches in early and late stages of embryonic development, and a significant decrease occurs between the intercept parameters. When egg loss varies significantly with female size, the slope of this relationship should change. 
In our material, significantly reduced intercept parameters in regressions of fecundity versus female $\mathrm{W}$ indicate substantial egg losses in P. pandaliformis and $M$. acanthurus. Calculation of theoretical egg numbers in early and late stages of development suggests that the percentage of egg loss in these species may amount to maximally about $23 \%$.

\section{Egg Size}

In decapods that reproduce in fresh water, egg size is frequently enlarged compared with that of marine relatives (Mashiko, 1982, 1983; Anger, 1995). Among the species studied here, we should thus expect the smallest eggs in the marine species $P$. northropi. In fact, they are smaller than in the limnic congener $P$. pandaliformis. However, they are larger than in $M$. olfersii, which is frequently encountered several kilometers upstream in rivers and mountain streams (McNamara and Moreira, 1987; López and Pereira, 1994). The difference in egg size between the two species of Macrobrachium is difficult to explain in this context, since these shrimps have a similar ecology. Thus, egg size is in these species apparently not related to ecological traits.

Within a group of related taxa, large eggs frequently indicate an enhanced endotrophic potential (lecithotrophy) of early larvae (Anger, 1995). In P. northropi, no experimental evidence of lecithotrophy has been shown, in spite of relatively large eggs. In contrast, all fresh-water palaemonids investigated here are known to develop through the first larval stage in the absence of food: $P$. pandaliformis (see Bakker, 1989), M. olfersii (see Moreira et al., 1979; McNamara et al., 1980), M. carcinus (see Choudhury, 1971a), M. acanthurus (see Choudhury, 1971b). This gives the larvae sufficient time to leave freshwater streams or rivers, where strong water currents may prevail and plankton production is low. In conclusion, egg size alone seems to be a poor predictor of the nutritional independence of early larvae, suggesting that the chemical composition of the eggs must also be considered (Anger, 1995).

\section{Reproductive Output}

The "mass-specific brood mass" (Clarke, 1987) or reproductive output, RO, is another frequently used parameter in life-history studies, quantifying the energetic investment of a species into egg production (Hines, 1982, 1988, 1991; Hartnoll, 1985; Clarke et al., 1991). For several species of pandalid, hippolytid, and crangonid shrimps, average RO values ranging from $12-24 \%$ (on a wetweight basis) were reported, increasing with rising environmental temperature (Clarke, 1987; Clarke et al., 1991). On a dry-weight basis, these values would probably be slightly higher, due to differential water content of the eggs and the female body (for recent discussion, see Luppi et al., 1997). Thus, the average $R O$ values measured in the present investigation (ranging from 15-22\%) compare well with those in temperate shrimps. In contrast, considerably lower ROs have been reported in most brachyuran and anomuran crabs (Hines, 1982, 1988, 1991; Lardies and Wehrtmann, 1996; Luppi et al., 1997). The marine species $P$. northropi had a significantly lower RO than all fresh-water shrimps in our study. Future comparative investigations should show whether this was a coincidence or a rule of reproductive ecology.

\section{ACKNOWLEDGEMENTS}

We thank the staff of the CEBIMar for kind hospitality and support, and Dr. D. Ismael for occasional help in measurements and egg counts. The first author acknowledges financial support from the German Academic Exchange Service, DAAD (Bonn) and the Coordenadoria de Aperfeiçoamento de Pessoal do Ensino Superior, CAPES (Brasilia).

\section{LiTERATURE Cited}

Anger, K. 1995. The conquest of freshwater and land by marine crabs: adaptations in life-history patterns and larval bioenergetics.-Journal of Experimental Marine Biology and Ecology 193: 119-145.

, and J. Harms. 1990. Elemental (CHN) and proximate biochemical composition of decapod crustacean larvae.-Comparative Biochemistry and Physiology 97B: 69-80.

Bakker, C. 1989. Cultivo em laboratório de Palaemon (Palaemon) pandaliformis (Stimpson, 1871) (Decapoda, Palaemonidae): descrição e influência da salinidade no desenvolvimento pós-embrionário. Thesis, Federal University of Paraná, Curitiba, Brazil. Pp. 1-89.

Bauer, R. T. 1991. Analysis of embryo production in a caridean shrimp guild from a tropical seagrass meadow.-In: A. Wenner and A. Kuris, eds., Crustacean egg production, Crustacean Issues 7: 181-191.

Bird, D. F., and Y. T. Prairie. 1985. Practical guidelines for the use of zooplankton length-weight regression equations.-Journal of Plankton Research 7: 955-960.

Chace, F. A. 1972. The shrimps of the SmithsonianBredin Caribbean expeditions with a summary of the West Indian shallow-water species (Crustacea: Decapoda: Natantia).-Smithsonian Contributions to Zoology 98: i-x, 1-179. 
, and H. H. Hobbs. 1969. The freshwater and terrestrial decapod crustaceans of the West Indies with special reference to Dominica.-Bulletin of the United States National Museum 292: 1-298.

Charnov, E. L. 1990 . Relative size at the onset of maturity (RSOM) is an interesting number in crustacean growth (Decapoda, Pandalidae).-Crustaceana 59: 108-109.

Choudhury, P. C. 1971a. Responses of larval Macrobrachium carcinus (L.) to variations in salinity and diet (Decapoda, Palaemonidae).-Crustaceana 20: 113-120. 1971 b. Laboratory rearing of larvae of the palaemonid shrimp Macrobrachium acanthurus (Wiegmann, 1836).-Crustaceana 21: 113-126.

Clarke, A. 1987. Temperature, latitude and reproductive effort.-Marine Ecology Progress Series 38: 89-99.

1993. Reproductive trade-offs in caridean shrimps.-Functional Ecology 7: 411-419.

- C. Hopkins, and M. Nilssen. 1991. Egg size and reproductive output in the deep-water prawn Pandalus borealis Krøyer, 1838.-Functional Ecology 5: 724-730.

Collart, O. O. 1991. Stratégie de reproduction de Macrobrachium amazonicum en Amazonie Centrale (Decapoda, Caridea, Palaemonidae).-Crustaceana 61: 253-270.

Corey, S. 1991. Comparative potential reproduction and actual production in several species of North American crayfish.-In: A. Wenner and A. Kuris, eds., Crustacean egg production, Crustacean Issues 7: 69-76.

, and D. M. Reid. 1991. Comparative fecundity of decapod crustaceans. I. The fecundity of thirty-three species of nine families of caridean shrimp.-Crustaceana 60: 270-294.

Dall, W., B. J. Hill, P. C. Rothlisberg, and D. J. Sharples. 1990. The biology of the Penaeidae.-Advances in marine biology 27: 1-489.

Dobkin, S. 1971. A contribution to knowledge of the larval development of Macrobrachium acanthurus (Wiegmann, 1836) (Decapoda, Palaemonidae).-Crustaceana 21: 294-297.

Donatti, O. S. 1986. Algunos aspectos bioecológicos del camarón Palaemonetes argentinus (Nobili, 1901) en el embalse San Roque, Cordoba (Argentina).-Revista de Hidrobiología Tropical 19: 45-60.

Dugger, D. M., and S. Dobkin. 1975. A contribution to knowledge of the larval development of Macrobrachium olfersii (Wiegmann, 1836) (Decapoda, Palaemonidae).-Crustaceana 29: 1-30.

Emmerson, W. D. 1985. Fecundity, larval rearing and laboratory growth of Palaemon pacificus (Stimpson) (Decapoda, Palaemonidae).-Crustaceana 49: 277 289.

Farmer, A. S. D. 1986. Morphometric relationships of commercially important species of penaeid shrimp from the Arabian Gulf, Kuwait.-Bulletin of Marine Science 7: 1-21.

Gabche, C. E., and H.-U. P. Hockey. 1995. Growth and mortality of the giant African river prawn Macrobrachium völlenhovenii (Herklots) (Crustacea, Palaemonidae) in the Lobe River, Cameroon: a preliminary evaluation.-Journal of Shellfish Research 14: 185-190.

Gomes Corrêa, M. M. 1977. Palemonídeos do Brasil (Crustacea - Decapoda - Natantia).-Dissertation, Federal University of Rio de Janeiro, Brazil. Pp. 1-136.

Gore, R. H., G. R. Kulczycki, and P. A. Hastings. 1978 A second occurrence of the Brazilian freshwater shrimp, Potimirim potimirim, along the central eastern Florida coast.-Florida Scientist 41: 57-62.

Guerao, G., J. Pérez-Baquera, and C. Ribera. 1994 Growth and reproductive biology of Palaemon xiphias Risso, 1816 (Decapoda: Caridea: Palaemonidae).Journal of Crustacean Biology 14: 280-288.

Hartnoll, R. G. 1985. Growth, sexual maturity and reproductive output.-In: A. M. Wenner, ed., Factors in adult growth. Crustacean Issues 3: 101-128.

_, and A. J. Salama. 1992. The effect of protein source of the growth of the prawn Palaemon elegans Rathke, 1837 (Decapoda, Caridea).-Crustaceana 63: 81-90.

Hines, A. H. 1982. Allometric constraints and variables of reproductive effort in brachyuran crabs.-Marine $\mathrm{Bi}$ ology 69: 309-320.

1988. Fecundity and reproductive output in two species of deep-sea crabs, Geryon fenneri and G. quinquedens (Decapoda: Brachyura).- Journal of Crustacean Biology 8: 557-562.

-1991. Fecundity and reproductive output in nine species of Cancer crabs (Crustacea, Brachyura, Cancridae).-Canadian Journal of Fisheries and Aquatic Sciences 48: 267-275.

Hoglund, H. 1943. On the biology and larval development of Leander squilla (L.) forma typica de Man.Svenska Hydrographiske Biologiske Kommission Skrifter, Ny Serie, Biologie 2: 1-43.

Holthuis, L. B. 1952. A general revision of the Palaemonidae (Crustacea, Decapoda, Natantia) of the Americas. II. The subfamily Palaemoninae.-Occasional Papers of the Allan Hancock Foundation 12: 1-396.

1959. The Crustacea Decapoda of Suriname (Dutch Guiana).-Zoologische Verhandelingen 44: 235-250, 291-296.

, and A. J. Provenzano. 1970. New distribution records for species of Macrobrachium with notes on the distribution of the genus in Florida (Decapoda, Palaemonidae).-Crustaceana 19: 211-213.

Kurata, H. 1962. Studies on the age and growth of Crustacea.-Bulletin of the Hokkaido Regional Fisheries Laboratory 24: 1-115.

Kuris, A. M. 1991. A review of patterns and causes of crustacean brood mortality.-In: A. Wenner and A. Kuris, eds., Crustacean egg production. Crustacean Issues 7: 117-141.

Kutkuhn, J. H. 1966. Dynamics of a penaeid shrimp population and management implications.-Fishery Bulletin, United States 65: 313-338.

Labão, V. L. 1977. Fisioecologia do Pitu, camarão d'água doce-Macrobrachium holthuisi Genofre \& Lobão, 1976. Crecimento, ciclo sexual, ciclo de muda em reação a fatores abióticos. Dissertation, University of São Paulo, Brazil. Pp. 1-97.

Lardies, M. A., and I. S. Wehrtmann. 1996. Aspects of the reproductive biology of Petrolisthes laevigatus (Guérin, 1835) (Decapoda, Anomura, Porecellanidae). Part I: Reproductive output and chemical composition of eggs during embryonic development.-Archive of Fishery and Marine Research 43: 121-135.

López, B., and G. Pereira. 1994. Contribución al conocimiento de los Crustáceos y Moluscos de la Peninsula de Paria. Parte I: Crustacea: Decapoda.Memoria 141: 51-75.

Lovett, D. L., and D. L. Felder. 1989. Application of regression techniques to studies of relative growth in crustaceans.-Journal of Crustacean Biology 9: 529- 539. 
Luppi, T. A., C. Bas, E. D. Spivak, and K. Anger. 1997. Fecundity of two grapsid crab species in the Laguna Mar Chiquita, Argentina.-Archive of Fishery and Marine Research 45: 149-166.

McNamara, J. C., and G. S. Moreira. 1987. $\mathrm{O}_{2}$ consumption and acute salinity exposure in the freshwater shrimp Macrobrachium olfersii (Wiegmann) (Crustacea: Decapoda): whole animal and tissue respiration.--Journal of Experimental Marine Biology and Ecology 113: 221-230.

, and P. S. Moreira. 1980. Respiratory metabolism of Macrobrachium olfersii (Wiegmann) zoea during the moulting cycle from eclosion to first ecdysis.-Biological Bulletin 159: 692-699.

$\longrightarrow$, L. C. Salomão, and E. A. Ribeiro. 1990. The effect of eyestalk ablation on haemolymph osmotic and ionic concentrations during acute salinity exposure in the freshwater shrimp Macrobrachium olfersii (Wiegmann) (Crustacea, Decapoda).-Hydrobiologia 199: 193-199.

Mashiko, K. 1982. Differences in both the egg size and the clutch size of the freshwater prawn Palaemon paucidens De Haan in the Sagami River.-Japanese Journal of Ecology 32: 445-451.

1983. Differences in the egg and clutch sizes of the prawn Macrobrachium nipponense (De Haan) between brackish and fresh waters of a river.-Zoological Magazine 92: 1-9.

1990. Diversified egg and clutch sizes among local populations of the fresh-water prawn Macrobrachium nipponense (de Haan).- -Journal of Crustacean Biology 10: 306-314.

Moreira, G. S., and J. C. McNamara. 1984. Physiological responses of the early zoeal stages of Palaemon pandaliformis Stimpson and Palaemon northropi (Rankin) to salinity variation.-Hydrobiologia 113: 165-169.

- - and P. S. Moreira. 1979. The combined effects of temperature and salinity on the survival and moulting of early zoeae of Macrobrachium holthuisi (Decapoda: Palaemonidae).-Boletim de Fisiologia Animal, São Paulo 3: 81-93.

-, , and -1982 . The effect of salinity on the metabolic rates of some palaemonid shrimp larvae.-Aquaculture 29: 95-100.

Ogawa, Y., and S. Kakuda. 1988. On the growth and life span of the population of lake prawn, Palaemon paucidens De Haan (Decapoda, Macrura, Palaemonidae) in the Ashida River.-Journal of the Faculty of Applied Biological Science, Hiroshima 27: 41-50.

Ohtomi, J. 1997. Reproductive biology and growth of the deep-water pandalid shrimp Plesionika semilaevis (Decapoda: Caridea).-_Journal of Crustacean Biology 17: 81-89.

Reeve, M. R. 1969. The laboratory culture of the prawn Palaemon serratus.-Fishery Investigations, Series II, 26: 1-38.

Reid, D. M., and S. Corey. 1991. Comparative fecundity of decapod crustaceans, III. The fecundity of fifty-three species of Decapoda from tropical, subtropical, and boreal waters.-Crustaceana 61: 308-316.

Rodrigues Capitulo, A., and L. R. Freyre. 1989. Demografía de Palaemonetes (Palaemonetes) argentinus Nobili (Decapoda Natantia). I. Crecimiento.-Limnobios 2: 744-756.
Rodríguez, A. 1987. Biología del langostino Penaeus kerathurus (Forskål, 1775) del golfo de Cádiz. III. Biometría, edad y crecimiento.--Investigación Pesquera 51: 23-37.

Santos, F. H., and J. C. McNamara. 1996. Neuroendocrine modulation of osmoregulatory parameters in the freshwater shrimp Macrobrachium olfersii (Wiegmann) (Crustacea, Decapoda).- Journal of Experimental Marine Biology and Ecology 206: 109-120.

Sawaya, M. P. 1946. Sobre alguns camarões de água doce do Brasil.-Zoologia, São Paulo, 11: 393-408.

Shafi, M., M. M. A. Quddus, and S. Nahar. 1977. Observations on the biology of the prawns Macrobrachium lamarrei Edwards and Macrobrachium mirabilis Kemp.-Bangladesh Journal of Scientific and Industrial Research 12: 137-142.

Shumway, S. E., H. C. Perkins, D. F. Schick, and A. P. Stickney. 1985. Synopsis of biological data on the pink shrimp, Pandalus borealis Krøyer, 1838.-FAO Fisheries Synopsis 144: 1-57.

Smalley, A. 1963. The genus Potimirim in Central America (Crustacea, Atyidae).--Revista de Biología Tropical 11: 177-183.

Sokal, R. R., and F. J. Rohlf. 1995. Biometry. The principles and practice of statistics in biological research, third edition.-W. H. Freeman \& Co., San Francisco, California. Pp. 1-887.

Somers, K. M. 1991. Characterizing size-specific fecundity in crustaceans.-In: A. Wenner and A. Kuris, eds., Crustacean egg production. Crustacean Issues 7: 357-378.

Souza, S. C., and G. S. Moreira. 1987. Salinity effects on the neuroendocrine control of respiratory metabolism in Macrobrachium olfersii (Wiegmann) (Crustacea, Palaemonidae).-Comparative Biochemistry and Physiology 87: 399-403.

Wenner, A. M., editor. 1985. Factors in adult growth.Crustacean Issues 3: 1-362.

- H. M. Page, and P. R. Siegel. 1985. Variation in size at onset of egg production.-In: A. M. Wenner, ed., Factors in adult growth. Crustacean Issues 3: 149-164.

Wickins, J. F. 1972. Experiments on the culture of the spot prawn Pandalus platyceros Brandt and the giant freshwater prawn Macrobrachium rosenbergii (de Man).-Fishery Investigations, Series II, 27: 1-23.

Willführ-Nast, J., H. Rosenthal, P. J. Udo, and F. Nast. 1993. Laboratory cultivation and experimental studies of salinity effects on larval development in the African river prawn Macrobrachium vollenhovenii (Decapoda, Palaemonidae).-Aquatic Living Resources 6: 115-137.

Yan, H.-Y. 1987. Comparative reproductive strategies of the grass shrimps, Palaemonetes vulgaris and $P$. pugio (Decapoda, Natantia) in great Sippewissett Salt Marsh, Massachusetts, U.S.A.-Crustaceana 52: 141-148.

RECEIVED: 3 November 1997.

ACCEPTED: 26 February 1998.

Addresses: (KA) Biologische Anstalt Helgoland, Meeresstation, P.O. Box 185, D-27483 Helgoland, Germany (e-mail: oekophys@ desy.de); (GSM) Universidade de São Paulo (USP), Instituto de Biociências, Caixa Postal 11.461, CEP 05422-970 São Paulo, SP, Brasil (e-mail: gmoreira@usp.br). 
http://www.jstor.org

\title{
LINKED CITATIONS
}

\author{
- Page 1 of 2 -
}

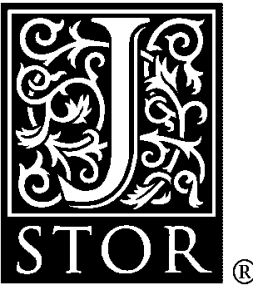

You have printed the following article:

Morphometric and Reproductive Traits of Tropical Caridean Shrimps

Klaus Anger; Gloria S. Moreira

Journal of Crustacean Biology, Vol. 18, No. 4. (Nov., 1998), pp. 823-838.

Stable URL:

http://links.jstor.org/sici?sici=0278-0372\%28199811\%2918\%3A4\%3C823\%3AMARTOT\%3E2.0.CO\%3B2-\%23

This article references the following linked citations. If you are trying to access articles from an off-campus location, you may be required to first logon via your library web site to access JSTOR. Please visit your library's website or contact a librarian to learn about options for remote access to JSTOR.

\section{Literature Cited}

\section{Reproductive Trade-Offs in Caridean Shrimps}

A. Clarke

Functional Ecology, Vol. 7, No. 4. (Aug., 1993), pp. 411-419.

Stable URL:

http://links.jstor.org/sici?sici=0269-8463\%28199308\%297\%3A4\%3C411\%3ARTICS\%3E2.0.CO\%3B2-0

Egg Size and Reproductive Output in the Deep-Water Prawn Pandalus borealis Kroyer, 1838

A. Clarke; C. C. E. Hopkins; E. M. Nilssen

Functional Ecology, Vol. 5, No. 6. (1991), pp. 724-730.

Stable URL:

http://links.jstor.org/sici?sici=0269-8463\%281991\%295\%3A6\%3C724\%3AESAROI\%3E2.0.CO\%3B2-2

Growth and Reproductive Biology of Palaemon xiphias Risso, 1816 (Decapoda: Caridea:

Palaemonidae)

G. Guerao; J. Pérez-Baquera; C. Ribera

Journal of Crustacean Biology, Vol. 14, No. 2. (May, 1994), pp. 280-288.

Stable URL:

http://links.jstor.org/sici?sici=0278-0372\%28199405\%2914\%3A2\%3C280\%3AGARBOP\%3E2.0.CO\%3B2-W 
http://www.jstor.org

\section{LINKED CITATIONS}

- Page 2 of 2 -

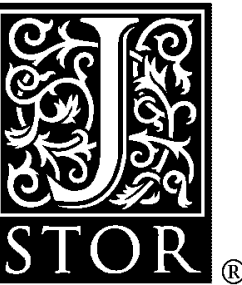

Fecundity and Reproductive Output in Two Species of Deep-Sea Crabs, Geryon fenneri and G. quinquedens (Decapoda: Brachyura)

Anson H. Hines

Journal of Crustacean Biology, Vol. 8, No. 4. (Nov., 1988), pp. 557-562.

Stable URL:

http://links.jstor.org/sici?sici=0278-0372\%28198811\%298\%3A4\%3C557\%3AFAROIT\%3E2.0.CO\%3B2-C

Application of Regression Techniques to Studies of Relative Growth in Crustaceans

Donald L. Lovett; Darryl L. Felder

Journal of Crustacean Biology, Vol. 9, No. 4. (Nov., 1989), pp. 529-539.

Stable URL:

http://links.jstor.org/sici?sici=0278-0372\%28198911\%299\%3A4\%3C529\%3AAORTTS\%3E2.0.CO\%3B2-V

Respiratory Metabolism of Macrobrachium olfersii (Wiegmann) Zoeae during the Moulting Cycle from Eclosion to First Ecdysis

John C. McNamara; Gloria S. Moreira; Plinio S. Moreira

Biological Bulletin, Vol. 159, No. 3. (Dec., 1980), pp. 692-699.

Stable URL:

http://links.jstor.org/sici?sici=0006-3185\%28198012\%29159\%3A3\%3C692\%3ARMOMO\%28\%3E2.0.CO\%3B2-L

Diversified Egg and Clutch Sizes among Local Populations of the Fresh-Water Prawn Macrobrachium nipponense (de Haan)

Kazuo Mashiko

Journal of Crustacean Biology, Vol. 10, No. 2. (May, 1990), pp. 306-314.

Stable URL:

http://links.jstor.org/sici?sici=0278-0372\%28199005\%2910\%3A2\%3C306\%3ADEACSA\%3E2.0.CO\%3B2-0

Reproductive Biology and Growth of the Deep-Water Pandalid Shrimp Plesionika semilaevis (Decapoda: Caridea)

Jun Ohtomi

Journal of Crustacean Biology, Vol. 17, No. 1. (Feb., 1997), pp. 81-89.

Stable URL:

http://links.jstor.org/sici?sici=0278-0372\%28199702\%2917\%3A1\%3C81\%3ARBAGOT\%3E2.0.CO\%3B2-H 